\title{
SORBUS PELSOENSIS (SORBUS SUBGENUS TORMARIA), A NEW SPECIES FROM THE SURROUNDINGS OF LAKE BALATON, HUNGARY
}

\author{
Csaba NÉMETH \\ Department of Botany and Soroksár Botanical Garden, Faculty of Horticultural Science \\ Corvinus University of Budapest, H-1118 Budapest, Ménesi út 44, Hungary; nemetcsaba@gmail.com
}

Németh, Cs. (2015): Sorbus pelsoensis (Sorbus subgenus Tormaria), a new species from the surroundings of Lake Balaton, Hungary. - Studia bot. hung. 46(1): 49-60.

\begin{abstract}
A new triploid Sorbus species, S. pelsoensis is described in Sorbus subgenus Tormaria (Sorbus latifolia group) from Balaton Uplands (Hungary). Illustrations (photographs of the type specimen, leaves, and fruits) and a detailed distribution map are provided as well as photographs of in situ flowering and fruiting individuals. S. pelsoensis is a stenoendemic species putatively derived from hybridisation between $S$. torminalis and $S$. graeca. The species is restricted to two neighbouring valleys with about 100 individuals found in thermophilous oak woodlands (Vicio sparsifloraeQuercetum pubescentis), pubescent oak shrub woodlands (Cotino-Quercetum pubescentis), mixed forests of rocky slopes (Primulo veris-Tilietum platyphyllae), mixed karstic forests (Fago-Ornetum), and at the light-rich margins of these plant communities, respectively.
\end{abstract}

Key words: endemic, Hungary, hybridisation, Sorbus latifolia agg., speciation, Tormaria

\section{INTRODUCTION}

Based on intensive field work and taxonomic research carried out in the recent years, several new Sorbus species have been described from the Bakony region (BARABits 2007, Németh 2007, 2009, 2012, SomLyay and Sennikov 2014), and the distributions of the existing Tormaria taxa have been clarified (NÉmeth 2006, 2013).

The Transdanubian Mountain Ranges, in particular the Bakony, Keszthely and Vértes Mts are particularly rich in Sorbus taxa derived through hybridisation between a member of S. aria agg. (subgen. Aria Pers.) and S. torminalis (L.) Crantz (subgen. Torminaria (DC.) C. Koch) resulting in apomictic species belonging to the nothosubgen. Tormaria Májovský et Bernátová (S. latifolia group). In contrast to these regions, the central and eastern parts of Balaton Uplands have been less studied for Sorbus, whilst the western area with its spectacular remnant basalt hills has been thoroughly explored (KÁRPÁTI 1960, NÉMETH 2014, SOMLYAY and SENNI KOV 2014).

Considering the localities of S. balatonica Kárp. listed by Kárpáti (1960), a distribution pattern is revealed that shows a conspicuously unusual disjunction with 
a central coherent area and further isolated localities separated from the central block. A similar pattern is observed in the well-known case of $S$. bakonyensis (Jáv.) Kárp. (KÁRPÁTI 1960, BARABITS 2007). This type of geographical distribution is not typical for apomictic Sorbus endemics. In the case of S. bakonyensis this anomaly was resolved by describing some isolated populations as distinct species (S. majeri Barabits, S. polgariana Cs. Németh, S. tobani Cs. Németh), and by revising the names of formerly misidentified gatherings (revised as $S$. danubialis (Jáv.) Kárp. and S. redliana Kárp.) (BARABITs 2007, NÉMETH 2007, 2012). This kind of disjunction is also observed in the distribution of S. balatonica (KÁRPÁTI 1960) displaying a more or less continuous area in Keszthely Mts, Sümeg-Tapolca Range and Szent György Hill, as well as a separated site in the eastern parts of Balaton Uplands near the settlements Felsöörs and Lovas, $40-50 \mathrm{~km}$ distant from the well-defined central block. Although the similarity of these eastern plants to $S$. balatonica in the main area is undisputable, a meticulous study of this Tormaria population reveals conspicuous morphological differences not only from $S$. balatonica but also from all other known Sorbus taxa. Based on these differences a new species is described here and the name S. pelsoensis is introduced for this endemic whitebeam population.

\section{MATERIAL AND METHODS}

Field work, plant material

Herbarium materials for the description were collected between 2011 and 2014. Geographical coordinates and altitudes were determined using Garmin eTrex Legend GPS. The nomenclature of the plant communities follows the work of BORHIDI (2003). The corresponding part of the Sorbus collection housed in the Hungarian Natural History Museum (BP) was also examined. Type specimens are deposited in BP; however, all paratypes are stored in the private collection of the author. Leaf comparison of the taxa is based on the broadest leaves taken from the middle part of sterile shoots, as recommended $e$. g. by MEYER et al. (2005) or RicH et al. (2009).

\section{RESULTS}

Sorbus pelsoensis Cs. Németh, spec. nova (Figs 1-3, 6-7)

Synonymy: S. balatonica Kárp. in Feddes Repert. 1960, p. 290 in part.

Holotype: Hungary, Balaton Uplands, Felsőörs, Malom-völgy, $47.02010^{\circ} \mathrm{N}$, $17.93321^{\circ} \mathrm{E}, 265 \mathrm{~m}, 03.06 .2012$, Cs. Németh no. HCsN 4342-1/2 (BP, accession number 739621) (Fig. 1). 


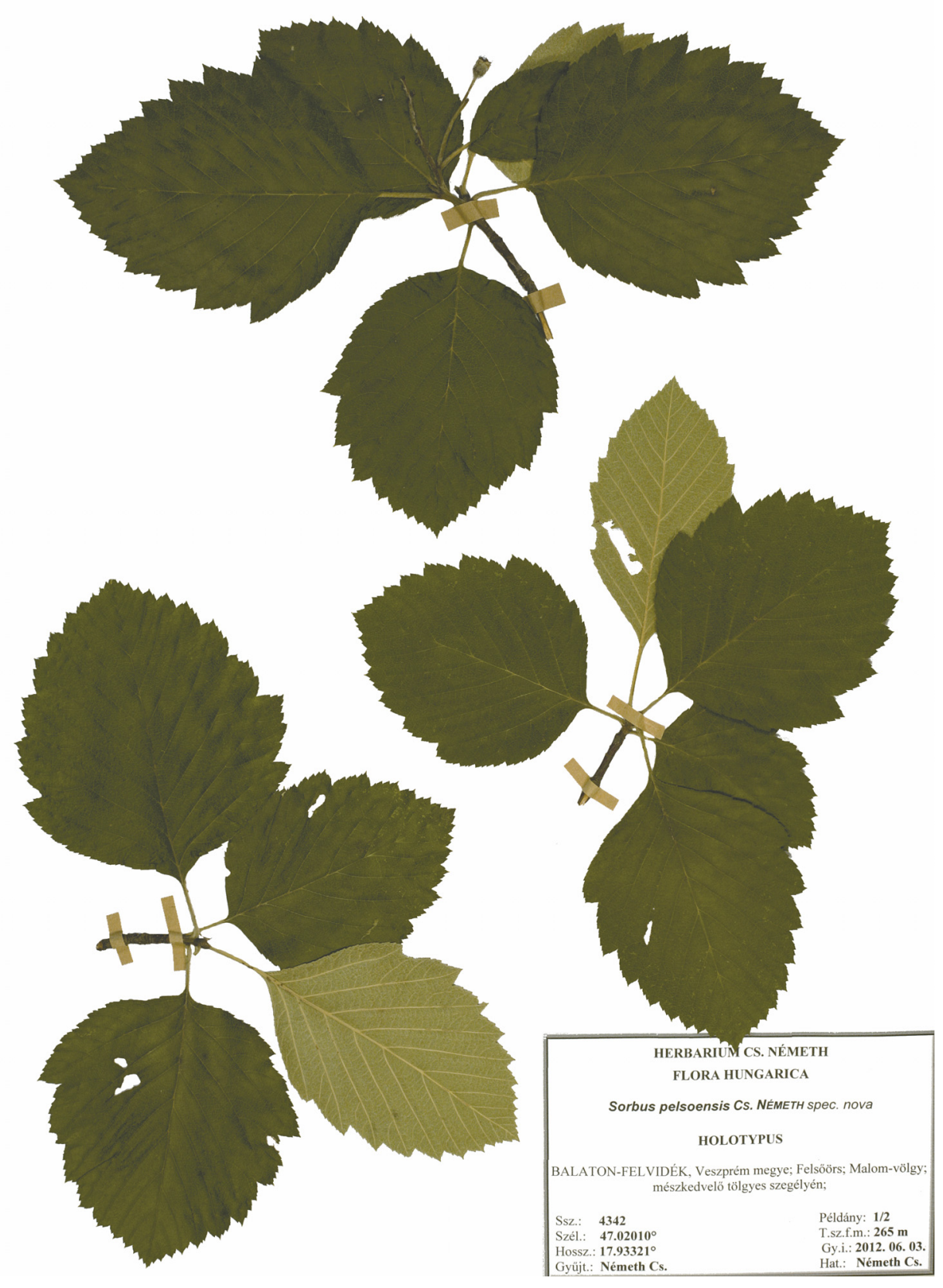

Fig. 1. The holotype of Sorbus pelsoensis. 
Isotype: no. $\mathrm{HCsN}$ 4342-2/2 (BP, accession number 739622).

Paratypes: Felsőörs: Malom-völgy (Á. Boros, 09.09.1957, BP 432690, BP 432691 sub S. balatonica), (Cs. Németh, 26.06.2011, HCsN 3652/1, HCsN 3652/2, HCsN 3652/3, HCsN 3653/1, HCsN 3652/2, HCsN 3654; 24.7.2011, HCsN 3717, HCsN 3718, HCsN 3719, HCsN 3720/1, HCsN 3721, HCsN 3722, HCsN 3723/1, HCsN 3725/2, HCsN 3726/1, HCsN3 727/3, HCsN 3729, HCsN 3730, HCsN 3733, HCsN 3736; 03.06.2012, HCsN 4339, HCsN 4341, HCsN 4344, HCsN 4345, HCsN 4346; 22.9.2013, HCsN 5039, HCsN 5045, HCsN 5047, HCsN 5049, HCsN 5051, HCsN 5054; 26.07.2014, HCsN 5936, HCsN 5937, HCsN 5940, HCsN 5942, HCsN 5943, HCsN5944, HCsN 5945, HCsN 5949, HCsN 5950, HCsN 5951); Lovas: Király-kúti-völgy (Cs. Németh, 24.07.2011, HCsN 3739/1, HCsN 3740/1, HCsN 3741/2, HCsN 3742/3; 22.09.2013, HCsN 5056, HCsN 5058, HCsN 5059).

\section{Description}

Tree to at least $8 \mathrm{~m}$. Bark of trunks grey. Buds ovoid, acute, pilose with white hairs on margins. Leaves simple, $7-10 \mathrm{~cm}$ long and $6.5-9 \mathrm{~cm}$ wide, widest in the lower part of lamina, upper surface dark green glossy with a convex surface between veins, lower surface greyish-green, texture relatively thin. Leaves from fertile shoots ovate to broadly ovate. Broad leaves of the middle part of short sterile shoots broadly ovate, orbicular-ovate, often as long as wide. Lobes of leaves from fertile shoots narrower and more acute, whilst leaves of sterile shoots have broader lobes with a more rounded outline. Apex shortly acuminate (rarely just acute), base broadly cuneate to rounded, shortly decurrent along petiole, number of lateral veins 9-10 on each lamina side. Length of the distal margin of the longest lobe (4-)5-7(-8) $\mathrm{mm}$, margin serrate. Petiole $1.3-2 \mathrm{~cm}$ (Fig. 2). Sepals narrowly triangular, tomentose. Petals $6 \mathrm{~mm} \times 4-5 \mathrm{~mm}$, white. Anthers 20, creamcoloured. Styles 2, split to base (Fig. 7). Fruits with viable seeds globose or subglobose, $10-12 \mathrm{~mm}$ in diameter, orange-red to red at maturity, sparsely spotted with medium lenticels (Fig. 3), fruits with abortive seeds smaller and orange in colour. Flowering in May, fruits maturing in September and October.

\section{Distinguishing from similar taxa}

The convex leaf lamina between the lateral veins give S. pelsoensis a characteristic appearance and distinguishes it from other known native Tormaria taxa at first sight. This feature is recognizable when viewing the plants from a distance of a few metres (Fig. 6).

Sorbus pelsoensis is most similar to $S$. balatonica from the adjacent Keszthely Mts, southern Bakony and Szent György Hill. It slightly resembles S. gayeriana Kárp. growing in the Keszthely Mts and southern Bakony as well as S. bakonyensis, 
a.
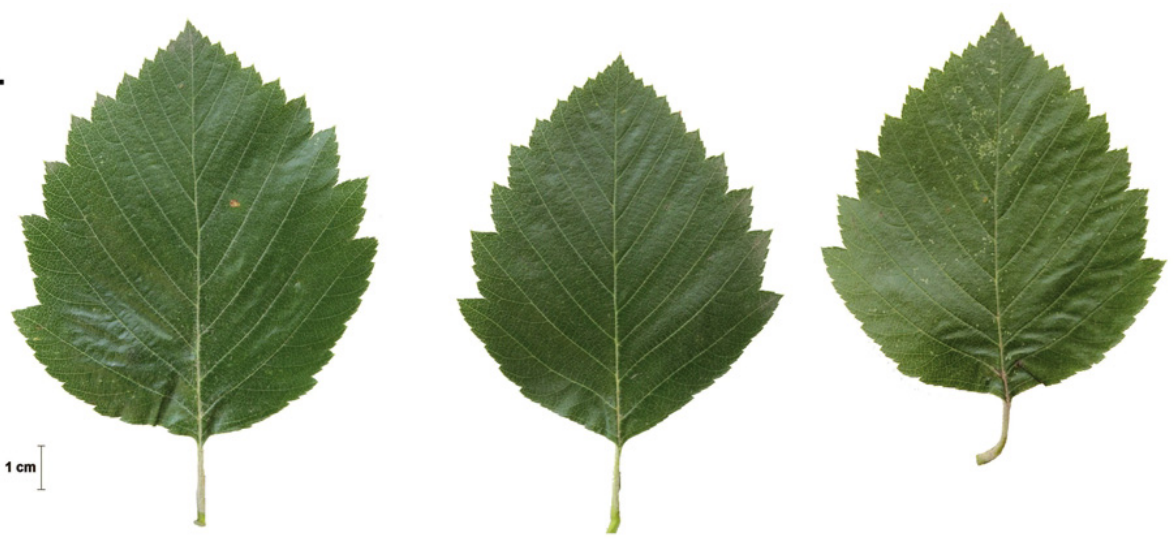

b.
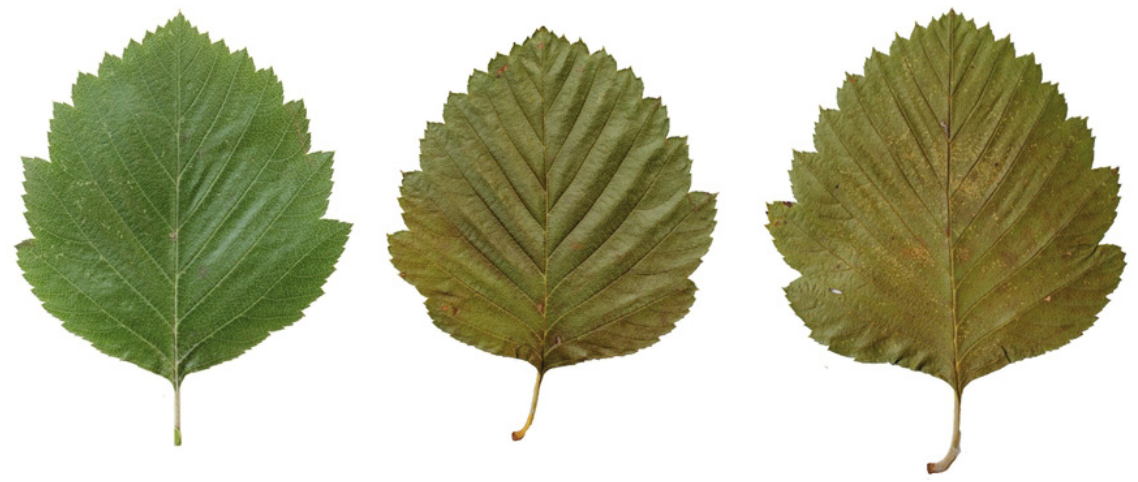

Fig. 2. Typical leaves of Sorbus pelsoensis; from fertile shoots (a); from sterile shoots (b).
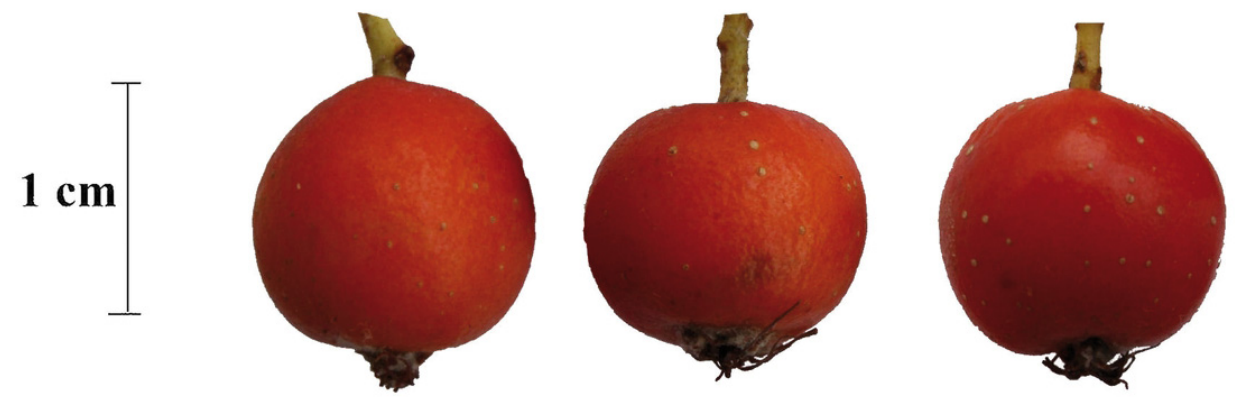

Fig. 3. Mature fruits of Sorbus pelsoensis containing viable seeds. 
a common endemic of the Keszthely Mts, southern Bakony and the basalt hills of the Tapolca Basin. In addition, it shows some resemblance with S. majeri, $S$. polgariana, and $S$. tobani, which were recently separated from the so-called " $S$. bakonyensis-group" (BARABITs 2007, NÉMETH 2007, 2012). From the above mentioned taxa, S. bakonyensis has the nearest occurrence (ca $20 \mathrm{~km}$ away at the valley Mina-völgy) to $S$. pelsoensis (NÉMETH 2013).

The main features distinguishing $S$. pelsoensis from similar Tormaria species of the surrounding areas are as follows (Fig. 4).

Sorbus balatonica has thicker leaf lamina; shorter (length of the distal margin of the longest lobe 3-5 mm), more acuminate lobes; whitish-grey, more densely hairy underneath; lobes more triangular in their outline.

Sorbus gayeriana has thicker leaves; broader, somewhat longer (length of the distal margin of the greatest lobe 6-10 $\mathrm{mm}$ ), more acuminate lobes with sharper teeth; brownish, densely lenticelled fruits.

Sorbus bakonyensis (sensu BARABits 2007 and NÉMETH 2013; S. udvardyana Somlyay et Sennikov sensu Somlyay and Sennikov 2014) has more rigid lamina; smaller, rhombic leaves with cuneate base not decurrent on the petiole; more finely and sharply acuminate lobes.

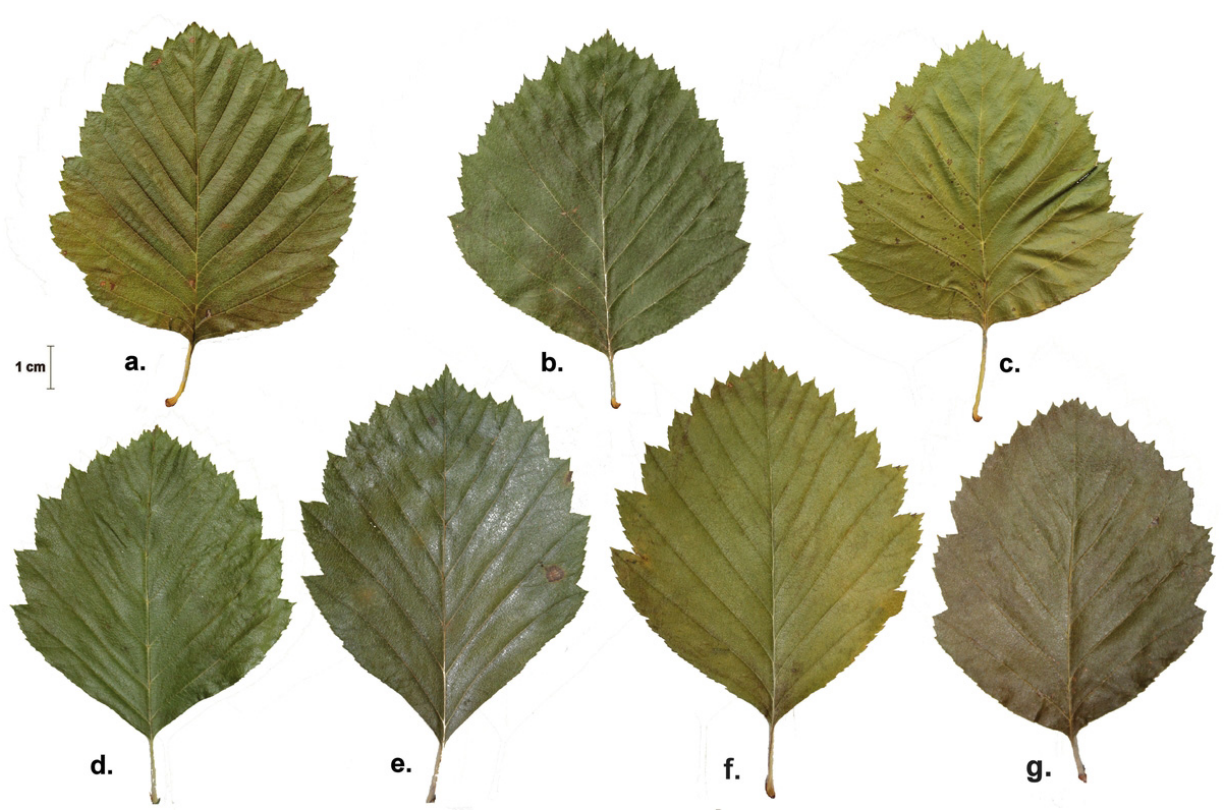

Fig. 4. Typical leaves from the middle part of sterile shoots of Sorbus pelsoensis (a) and the most similar taxa S. balatonica (b) and S. gayeriana (c), as well as moderately similar species $S$. bakonyensis (d), S. majeri (e), S. polgariana (f), S. tobani (g) from the adjacent areas. 
Sorbus majeri (sensu BARABITs 2007 and NÉMETH 2013; S. bakonyensis sensu SomLYaY and SENNikov 2014) has elliptic to elliptic-ovate leaf shape; more cuneate leaf base; fewer pairs of lateral vein (8-9); whitish-grey underneath.

Sorbus polgariana has ovate-elliptic to broadly ovate-elliptic leaf shape; slightly longer (length of the distal margin of the longest lobe 8-9 $\mathrm{mm}$ ), narrower and more acute lobes; more cuneate leaf base.

Sorbus tobani has orbicular-elliptic to elliptic leaves; smaller lobes (length of the distal margin of the greatest lobe 3-5 $\mathrm{mm}$ ); densely tomentose, whitish-grey lower surface; obtuse leaf apex.

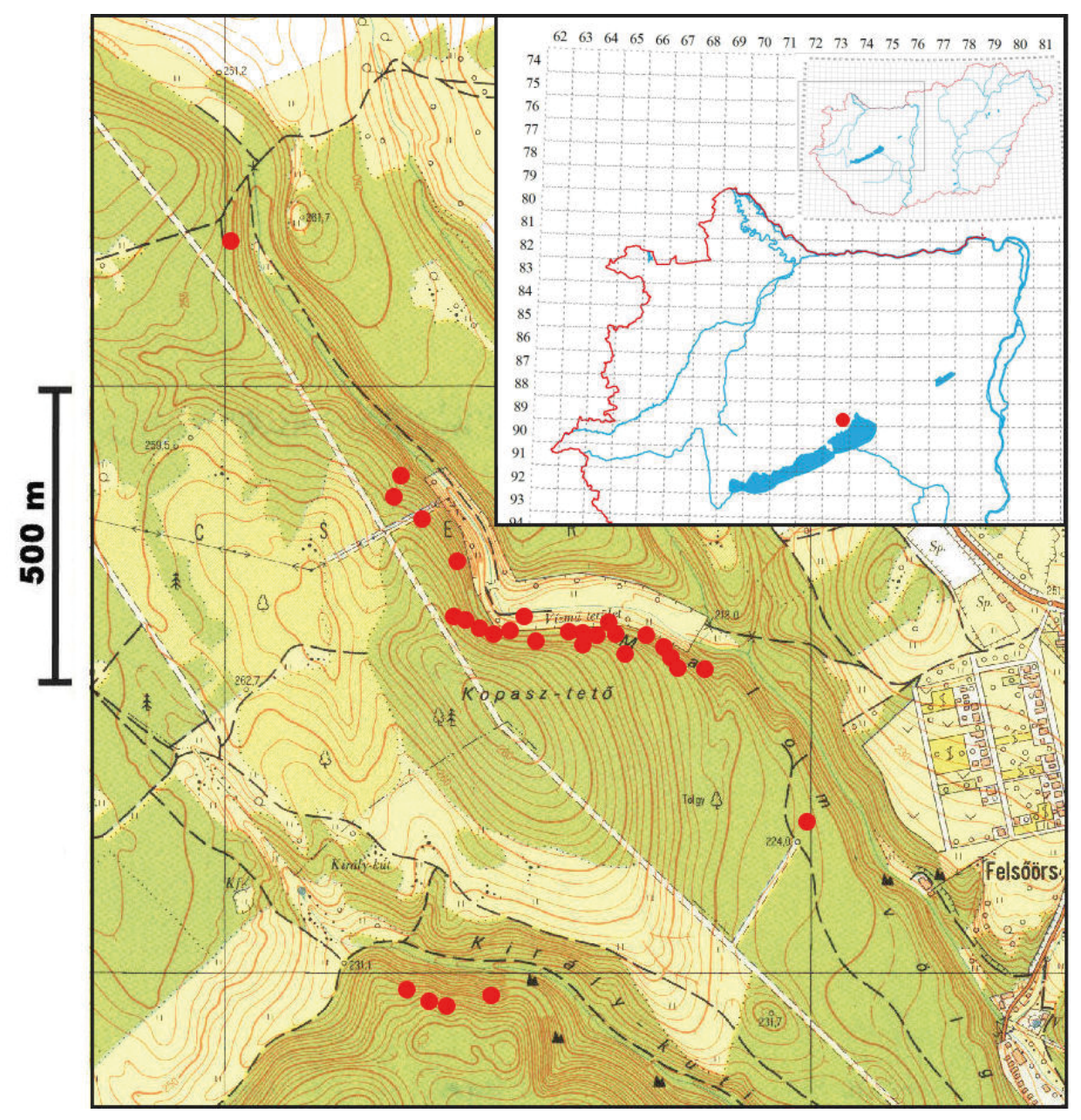

Fig. 5. Distribution of Sorbus pelsoensis. 
Geographical distribution, population size and conservation status

Sorbus pelsoensis is restricted to two valleys that are located within $c a 600 \mathrm{~m}$ from each other. The largest subpopulation with about $90 \%$ of the plants is situated in the middle part of valley Malom-völgy. The second smaller subpopulation with about $10 \%$ of the plants occurs in the neighbouring Király-kúti-völgy (Fig. 5).

The total population size of $S$. pelsoensis is estimated to about 100 individuals. The population is diversified with respect to age, consisting of fertile, adult trees and young individuals from sapling to larger but still not fertile trees of different ages.

All the occurrences fall into the grid cell 8973.4 and both of the valleys where the species grows are protected by law.

According to IUCN (2001) the threat status proposed for S. pelsoensis is critically endangered $(\mathrm{CR})$ :

Criterion B: area of occupancy to be about $1 \mathrm{~km}^{2}$.

Criterion C: the population size is about 100 individuals.

Criterion D: number of mature individuals was estimated to be fewer than 50 trees.

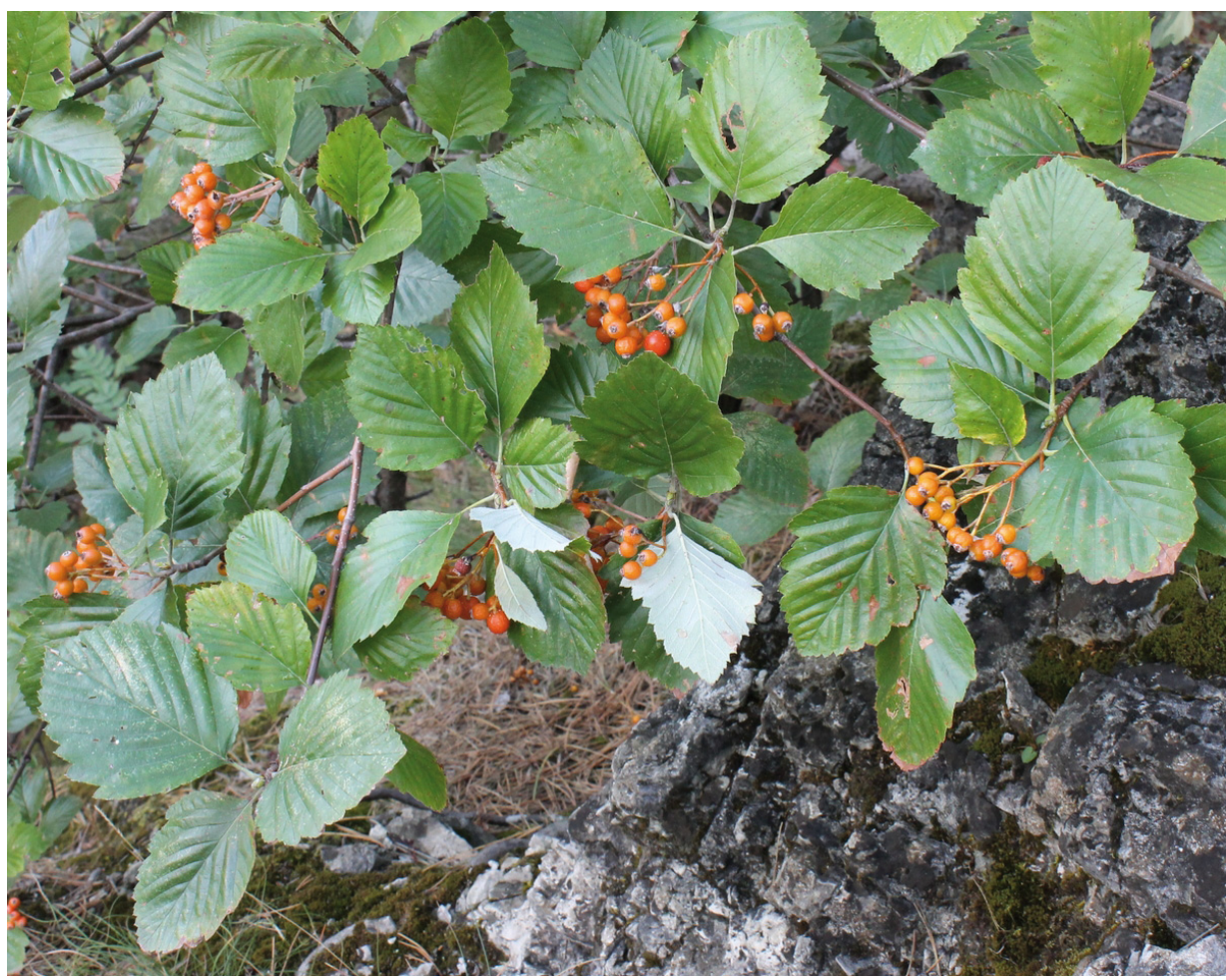

Fig. 6. Sorbus pelsoensis in its natural habitat in valley Malom-völgy, showing characteristic appearance of the convex leaf lamina between lateral veins (22.09.2013). 


\section{Origin}

On the basis of morphological features Sorbus pelsoensis is obviously a member of subgenus Tormaria (Sorbus aria agg. $\times$ Sorbus torminalis). It possesses triploid $(2 \mathrm{n} \sim 51)$ cytotype (Németh $e t$ al. in prep.) and has probably been derived from hybridisation between the diploid $(2 \mathrm{n}=34) S$. torminalis and either S. graeca (Spach) Lodd. or S. danubialis (both are tetraploid, $2 \mathrm{n} \sim 68$ (Németh $e t$ al. in prep.)) occurring sympatrically. According to the leaf morphology, S. graeca is more likely to be one of the parent species than $S$. danubialis. The presumably asexual (apomictic) reproductive mode of $S$. pelsoensis is indicated by both the morphological uniformity and polyploidy.

\section{Etymology}

The epithet "pelsoensis" refers to the name of Lake Balaton in the Roman age (Lacus Pelso) when the Transdanubian region belonged to the Roman Empire as a distinct province, Pannonia. Since the Hungarian epithet "balatoni" has already

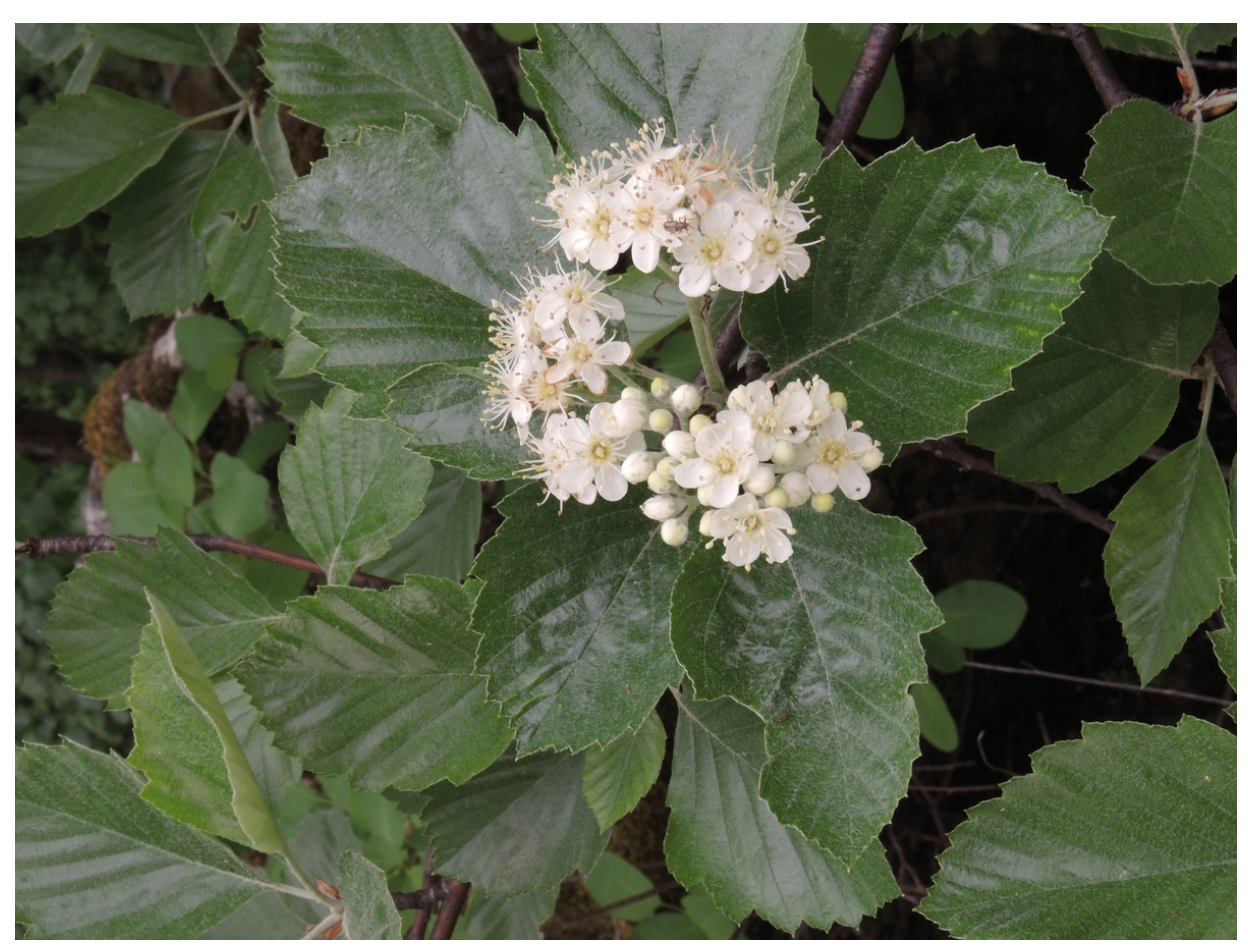

Fig. 7. Flowering shoot of Sorbus pelsoensis in valley Király-kúti-völgy (photo: Gábor Mészáros, 05.05.2013). 
been reserved for S. balatonica (KÁRPÁTI 1949), based on the immediate vicinity of the village Felsöörs to the main site of $S$. pelsoensis, "felsöörsi berkenye" is proposed as its Hungarian vernacular name.

\section{Coenology}

Sorbus pelsoensis grows in closed thermophilous oak woodlands (Vicio sparsiflorae-Quercetum pubescentis Zólyomi ex Borhidi et Kevey 1996), pubescent oak shrub woodlands (Cotino-Quercetum pubescentis Soó (1931) 1932), mixed forests of rocky slopes (Primulo veris-Tilietum platyphyllae (Isépy 1968) Borhidi 1996) and mixed karstic forests (Fago-Ornetum Zólyomi (1950) 1958) that are occasionally mixed with planted pine trees (Pinus nigra J. F. Arnold), or at the margin of these assemblages always with a northern or northeastern aspect.

\section{Phenotypic variation}

Apart from the generally experienced within-individual variation of leaf morphology in Sorbus taxa (MEYER et al. 2005, RICH et al. 2009), no variability can be observed in the S. pelsoensis population.

\section{History}

According to the present knowledge, Sorbus pelsoensis was first collected by Ádám Boros on 9 September of 1957 in the valley Malom-völgy and determined as $S$. balatonica according to the labels of herbarium specimens (BP 432690, BP 432691). However, contrary to this determination, in his floristical diaries (Boros 1915-1971) the note "bakonyensis" can be read (written in pencil instead of the usual pen probably because of his uncertainty concerning the correctness of the identification) with a short addition "bőven, szép [abundant, nice]". Three years later this occurrence was published by KÁRPÁTI (1960) in his Sorbus monograph under the name $S$. balatonica. Recently, BAUER (2015) rediscovered the population and identified it as $S$. udvardyana.

\section{DISCUSSION}

With Sorbus pelsoensis the number of Sorbus subgen. Tormaria taxa known from Hungary has increased to 31. Apart from S. balatonica and S. bakonyensis growing on basalt hills of the western part of Balaton Uplands, S. pelsoensis is the third taxon from this hybridogenous group that occurs in the region. While the former two taxa can also be found in the adjoining landscape units such as the Bakony and Keszthely Mts, S. pelsoensis can be regarded as the only Sorbus 
endemic to the Uplands. The population of approximately 100 individuals is geographically isolated from any other Tormaria species but shares its habitat with the widely distributed $S$. danubialis, $S$. graeca (from subgen. Aria) as well as $S$. torminalis that played a crucial role in its origin by interspecific hybridisation. The S. pelsoensis population does not exhibit any phenotypic variability, probably due to apomixis (way of asexual reproduction by means of seeds), a phenomenon that can be experienced across the genera causing intraspecific genetic uniformity, actually clonality.

Acknowledgements - The author would like to thank Gábor Mészáros for his help in the field work and Peter Erzberger for linguistic corrections. Thanks are due to reviewers for their comments on the draft.

Összefoglaló: A Dunántúli-középhegység berkenyeflórája európai mércével mérve is rendkívül alakgazdag és már közel 150 esztendeje kutatott. A vonulat többi tagjához viszonyítva a Balaton-felvidék Sorbus-kutatásának - a Tapolcai-medence bazalt tanúhegyeit leszámítva - valamivel alárendeltebb szerep jutott, ennek megfelelően az MTM Növénytárának herbáriuma is viszonylag kisszámú, a területet reprezentáló gyűjtéssel rendelkezik. E példányok közé tartozik a felsőörsi Malom-völgyből származó, a Tormaria alnemzetséghez (Sorbus aria agg. $\times$ Sorbus torminalis) tartozó berkenye két herbáriumi lapja is, melyet Boros Ádám 1957-ben gyüjtött és florisztikai jegyzeteiben $S$. bakonyensis bejegyzéssel regisztrált, a példányok céduláin viszont $S$. balatonica néven határozott. Az előfordulás végül az utóbbi név alatt került publikálásra Kárpáti Zoltán 1960ban megjelent Sorbus monográfiájában. A területet érintő recens terepbejárások megfigyelései és a gyüjtött herbáriumi összehasonlító anyagok alapján ezzel szemben az állapítható meg, hogy a Felsőörs határában húzódó Malom-völgy, valamint a szomszédos Lovas községhez tartozó Királykúti-völgy északi, északkeleti kitettségű sziklás lejtőinek mészkedvelő tölgyeseiben, hársas dolomittörmeléklejtő erdeiben és elegyes karszterdeiben élő, változatos koreloszlást mutató, kb. 100 egyedből álló Tormaria populáció sem a $S$. bakonyensis, sem a $S$. balatonica fajokkal, sem más, ez idáig leírt berkenyetaxonnal nem azonosítható. A populáció a tájegység saját endemizmusaként az alábbiakban S. pelsoensis néven kerül leírásra. Ezzel a Balaton-felvidékről ismert Tormaria taxonok száma a Tapolcai-medence tanúhegyein előforduló S. bakonyensis és $S$. balatonica fajokkal együtt háromra, a teljes hazai flórát tekintve pedig harmincegyre emelkedett.

\section{REFERENCES}

BARABits, E. (2007): A Sorbus bakonyensis (Jáv.) Kárp. taxonómiai revíziója - új berkenye fajok a magyar flórában. (New apomictic taxa of Sorbus from the Bakony Mountains). - Tilia 13: 5-48.

BAUER, N. (2015): Sorbus udvardyana Somlyay \& Sennikov a Balaton-felvidék keleti dolomitterületén. - Kitaibelia 20(1): 55-58. http://dx.doi.org/10.17542/kit.20.55

BorHIDI, A. (2003): Magyarország növénytársulásai. [Plant communities of Hungary]. - Akadémiai Kiadó, Budapest, $610 \mathrm{pp}$

Boros, Á. (1915-1971): Florisztikai jegyzetek. [Field diaries]. - Manuscript, Hungarian Natural History Museum, Budapest. 
IUCN (2001): IUCN red list categories and criteria. Version 3.1. - IUCN-SCC (http://www.iucnredlist.org/technical-documents/categories-and-criteria) (accessed 25.04.2015).

KÁrPÁti, Z. (1949): Taxonomische Studien über die zwischen Sorbus aria und Sorbus torminalis stehenden Arten und Bastarde im Karpathenbecken. - Hung. Acta Biol. 1(3): 94-125.

KÁRPÁTI, Z. (1960): Die Sorbus-Arten Ungarns und der angrenzenden Gebiete. - Feddes Repert. 62: 71-331.

Meyer, N., Meierott, L. and Angerer, O. (2005): Beiträge zur Gattung Sorbus in Bayern. - Ber. Bayer. Bot. Ges. 75: 5-216.

NÉmeth, Cs. (2006): Hibrid eredetü, bennszülött Sorbus taxonok elterjedése a Vértesben és környékén. (Distribution of endemic hybridogenous Sorbus taxa in the Vértes Mts. and its surroundings). - Flora Pannonica 4: 17-33.

NÉMETH, Cs. (2007): Új berkenye kisfaj a magyar flórában Sorbus tobani Németh. (Sorbus tobani, a new whitebeam microspecies in the Hungarian flora). - Flora Pannonica 5: 173-184.

NÉmeth, Cs. (2009): Új berkenye (Sorbus) kisfajok a Vértesből. (New Sorbus species from the Vértes Mts). - Kitaibelia 14(1): 89-103.

NÉmETH, Cs. (2012): Two new Sorbus (Rosaceae) species from the Bakony Mts, Hungary. - Acta Bot. Hung. 54(1-2): 131-144.

NÉmeth, Cs. (2013): Hibrid eredetü, bennszülött Sorbus aria s. $1 . \times$ Sorbus torminalis taxonok (nothosubgenus Tormaria, S. latifolia agg.) elterjedése a Bakonyban. (Distribution of hybridogeneus endemic Sorbus aria s. 1. $\times$ Sorbus torminalis taxa (nothosubgenus Tormaria, $S$. latifolia agg.) in the Bakony Mts). - Kitaibelia 18(1-2): 89-104.

NÉmetr, Cs. (2014): Apomiktikus Sorbus taxonok a Tapolcai-medence bazalt tanúhegyein. [Distribution of apomictic Sorbus taxa on the basalt remnant hills of the Tapolca Basin]. - Abstracts, Aktuális Flóra- és Vegetációkutatás a Kárpát-medencében X, Sopron, p. 196.

Rich, T. C. G., Houston, L., Robertson, A. and Proctor, M. C. F. (2009): Service trees, rowans and whitebeams of Britain and Ireland. - Botanical Society of the British Isles, 223 pp.

Somlyay, L. and Sennikov, A. (2014): Atlas Florae Europaeae notes 23. The typification and revised taxonomic circumscription of Sorbus bakonyensis (Rosaceae), with a description of Sorbus udvardyana, a new apomictic species endemic to Hungary. - Phytotaxa 164(4): $265-275$.

(submitted: 03.02.2015, accepted: 30.04 .2015 ) 